\title{
Current Insights in the Development of Efficacious Vaccines Against RSV
}

\author{
Jorge A. Soto ${ }^{1}$, Laura M. Stephens ${ }^{2}$, Kody A. Waldstein ${ }^{2}$, Gisela Canedo-Marroquín ${ }^{1}$, \\ Steven M. Varga ${ }^{2,3,4}$ and Alexis M. Kalergis ${ }^{1,5 *}$ \\ 'Departamento de Genética Molecular y Microbiología, Facultad de Ciencias Biológicas, Instituto Milenio de Inmunología e \\ Inmunoterapia, Pontificia Universidad Católica de Chile, Santiago, Chile, ${ }^{2}$ Interdisciplinary Graduate Program in Immunology, \\ University of lowa, lowa City, IA, United States, ${ }^{3}$ Department of Microbiology and Immunology, University of lowa, lowa City, \\ IA, United States, ${ }^{4}$ Department of Pathology, University of lowa, lowa City, IA, United States, ${ }^{5}$ Departamento de \\ Endocrinología, Facultad de Medicina, Instituto Milenio de Inmunología e Inmunoterapia, Pontificia Universidad Católica de \\ Chile, Santiago, Chile
}

Keywords: Respiratory Syncytial Virus, treatments, vaccines, antibodies, $\mathrm{T}$ cells

\section{INTRODUCTION}

Respiratory viral infections are one of the most important global public health burdens, resulting in millions of hospitalizations worldwide annually $(1,2)$. Respiratory Syncytial Virus (RSV) is the leading cause of acute lower respiratory tract infections (ALRTI) in children under the age of 2 (3) and adults over 65 (4). RSV-induced disease can range from symptoms similar to the common cold to complex respiratory diseases, such as pneumonia or bronchiolitis, leading to extrapulmonary sequelae in the brain and other tissues (5). During the 1960s, a formalin-inactivated RSV (FI-RSV) vaccine was evaluated in children. Vaccinated individuals exhibited increased disease severity upon

OPEN ACCESS

Edited by:

Xulin Chen,

Jinan University, China

Reviewed by:

Xuguang $L i$

Health Canada, Canada

*Correspondence:

Alexis M. Kalergis

akalergis@bio.puc.cl

Specialty section:

This article was submitted to

Viral Immunology,

a section of the journal

Frontiers in Immunology

Received: 31 March 2020

Accepted: 09 June 2020

Published: 17 July 2020

Citation:

Soto JA, Stephens $L M$, Waldstein KA, Canedo-Marroquín G, Varga SM and Kalergis AM (2020) Current Insights in

the Development of Efficacious

Vaccines Against RSV.

Front. Immunol. 11:1507.

doi: 10.3389/fimmu.2020.01507 subsequent natural RSV infection compared to the controls (6-9). This vaccine-enhanced disease resulted from the failure of the vaccine to elicit either potent neutralizing antibodies or memory $\mathrm{CD}^{+} \mathrm{T}$ cells as well as the induction of a strong inflammatory CD4 T cell response (10-13). Currently, the only treatment option available for RSV is a humanized monoclonal antibody against the RSV F surface protein, known as palivizumab (14). However, its usage is limited to high-risk individuals, such as preterm babies, and infants with congenic diseases (15-17). Due to prolonged concerns about vaccine safety, a better understanding of RSV-induced pathogenesis and the host immune response is needed to aid in the development of safe and effective treatments and vaccines for RSV. This Opinion article examines the various vaccine modalities currently undergoing testing and discusses the advantages and disadvantages of the strategies being employed.

\section{RSV VACCINE MODALITIES AND LESSONS FROM THE HOST IMMUNE RESPONSE}

Based on the knowledge gained from the unsuccessful FI-RSV vaccine trial, new vaccine formulations are being developed that promote neutralizing antibodies, induce activated memory and lung-resident $\mathrm{CD} 8^{+} \mathrm{T}$ cells, and can be administered to different target populations including children, elderly and pregnant women. The most promising vaccine candidates currently being evaluated in humans are live-attenuated, recombinant vector-based, and subunit vaccines.

Live-attenuated vaccines demonstrate favorable benefits including a low risk of causing vaccineenhanced disease, and they can promote both a humoral and cellular immune response. However, potential drawbacks include conserving the stability of the formulation, and balancing the attenuation of the virus while maintaining replicative activity and immunogenicity in the host (18). Additionally, further studies are needed to assess the safety of live-attenuated vaccines in multiple populations (19). Many live-attenuated vaccines are currently undergoing testing in clinical trials and demonstrate a robust induction of a humoral immune response; however, much 
less information is known about the cellular immune responses induced by the vaccines. Deletion of the M2-2 protein from the RSV strain A2 (LID $\Delta$ M2-2) induced robust serum RSV-specific IgG and neutralizing antibody titers that correlated with lower nasal wash viral titers administered intranasally to seronegative children (20). A similar induction of serum neutralizing antibodies was observed with a cold-passage/stabilized RSV containing several attenuating point mutations as well as deletion of the small hydrophobic (SH) protein (RSVcps2) (21). Finally, preclinical studies of a recombinant BCG vaccine expressing the RSV nucleoprotein $(\mathrm{N})$ demonstrated an effective cellular and humoral immune response in mice (22-25).

Recombinant vector-based vaccines allow the presentation of one or more antigens expressed on a viral vector such as parainfluenza virus type 3 (PIV3) or adenovirus. This allows for natural presentation of the antigen of interest to immune cells. A PIV3 vector expressing the RSV F protein (MEDI-534) demonstrated safety in a Phase 1 study when administered intranasally to young children (26). Interestingly, some discordance was observed in the specificity of the immune response. Sequencing of viral samples suggested that modifications were generated post-vaccination in a number of subjects that promoted a reduction in the expression of the $\mathrm{F}$ protein correlating with lower neutralizing antibodies in those individuals (27). A recently developed vaccine composed of a chimpanzee adenovirus viral vector expressing the RSV $\mathrm{F}, \mathrm{N}$, and M2-1 proteins (ChAd155-RSV) induced robust neutralizing antibody titers and interferon gamma (IFN $\gamma$ )secreting T cells compared to placebo controls (28). ReiThera Srl developed a similar vaccine using a chimpanzee adenovirus (PanAd3) viral vector expressing the RSV F, N, and M2-1 proteins in combination with a modified vaccinia virus Ankara (MVA). Intramuscular and intranasal delivery of the vaccine to healthy adults was well tolerated and induced both RSVspecific antibody titers and RSV-specific CD4 and $\mathrm{CD}^{+} \mathrm{T}$ cells (29-31). Interestingly, other clinical trials using adenovirus have been developed to date (NCT03982199, NCT03636906, among others).

Subunit vaccines are a common vaccine modality; however, some disadvantages are associated with these formulations such as the frequent need to use an adjuvant to increase the immunogenicity. A single dose of an RSV F protein subunit vaccine combined with aluminum hydroxide induced RSV Fspecific antibodies that persisted for $>180$ days post-vaccination (32). Similar results were observed following intramuscular administration to women of child-bearing age, suggesting that maternal immunization with this vaccine candidate could generate lasting antibodies to passively transfer to the fetus during the pregnancy (33). Another vaccine utilizing the RSV $\mathrm{F}$ protein demonstrated safety and efficacy in Phase 1 and Phase 2 clinicals trials when administered without an adjuvant, suggesting that a subunit vaccine may induce lasting protection without an added adjuvant (34). Interestingly, formulations using the RSV F protein have failed to provide protection against RSV infection in older adult populations, indicating that subunit vaccines may not be the best candidate for this target population (35).
Many vaccine prototypes are focused on viral surface proteins $(36,37)$. One of the most common viral targets for antibodies is the RSV fusion (F) protein $(38,39)$. Vaccine formulations containing the $\mathrm{N}$ protein also induce long-lasting neutralizing antibodies and could serve as a novel antiviral target (22, 25). The RSV G protein is involved in the initiation of the virus life cycle and has a potent effect on the regulation of the immune response (36). The SH protein can promote a protective immune response in animal models of RSV through Fc receptor-mediated interactions with macrophages and helping the promotion of long-lasting antibodies $(40,41)$. Furthermore, other protein targets are currently being or have been evaluated in clinical trials, including the nonstructural protein 2 (NS2) (NCT03596801, NCT03473002) and the M2-2 protein (20, 42). However, independent of the antigen evaluated, the key requirement of any RSV vaccine is the ability to promote a safe, but effective and protective immune response.

On the other hand, another type of vaccine strategy that has provided positive and interesting results in human tests is based on intranasal administration of a novel BLP (bacterium like particle) conjugated to the RSV fusion (F) protein eliciting both mucosal IgA responses and elevated IFN- $\gamma$ production (43). Since BLP prototype is a promising strategy, more assays to evaluate long-lasting immune response are required.

The choice of administration route is an important decision in vaccine development, with most vaccines being delivered via the sublingual, intramuscular, or intranasal route. Sublingual administration of an RSV G protein vaccine induced enhanced cellular infiltration and pro-inflammatory cytokine production compared to intranasal delivery (37). Similar results were observed when a recombinant RSV attachment (G) protein containing the central regions for both RSV A and B serotypes was administrated either intranasally or sublingually (44). Sublingual delivery enhanced pulmonary eosinophil recruitment and body weight loss, while intranasal administration promoted enhanced IgG and IgA antibodies and lower pro-inflammatory cell recruitment into the lung. Mucosal administration may also induce a high titer of IgA in bronchial alveolar lavage (BAL) fluid and IgG antibodies in serum $(44,45)$. A murine cytomegalovirus vector expressing the RSV matrix (M) protein induced robust lung-resident memory $\mathrm{T}$ cell populations when administered intranasally compared to intraperitoneally, where this population was almost undetectable $(46,47)$. This suggests that intranasal administration of an RSV vaccine would induce an enhanced $\mathrm{CD}^{+} \mathrm{T}$ cell response, a strong secretion of IgG and IgA antibodies, and decrease the inflammatory state of the lung.

One way to aid in the successful development of an RSV vaccine is to gain a better understanding of the host immune response to the virus and the factors required for long-term immunity. Studies examining the host response during acute infection of infants suggest that the virus elicits a pathogenic Th2 dominant response (10-13). Th2-biased $\mathrm{T}$ cells, driven by IL-4, IL-5, and IL-13 cytokines, lead to inflammation and hyperreactivity of the airways (48-51). Other T cell populations, including regulatory $\mathrm{T}$ cells (Tregs) and Th17 cells, also play an important role during RSV infection (52). Th17 cells can promote a pro-inflammatory state leading to enhanced neutrophil 
recruitment and reduced $\mathrm{CD}^{+}{ }^{-} \mathrm{T}$ cell activation (53). Tregs are associated with the active recruitment of cytotoxic $\mathrm{CD} 8^{+}$ $\mathrm{T}$ cells in the lung; however, unbalanced Tregs could promote enhanced lung damage $(54,55)$. Interestingly, peripheral blood mononuclear cells (PBMCs) from infected children exhibit reduced Tregs compared to age-matched controls (56). Similarly, depletion of Tregs in mice promoted enhanced lung pathology following RSV infection $(57,58)$. Thus, a successful vaccine should induce a balanced $\mathrm{T}$ cell response characterized by Th1biased $\mathrm{T}$ cells as well as Tregs.

The induction of type I IFN are essential for RSV viral clearance. The absence of type I IFN promotes a proinflammatory response that helps to induce a lung pathology in both human and murine models of infection (59). The administration of IFN- $\alpha$ in RSV-naive high-risk infants is associated with a decrease in lung pathology and enhanced viral clearance. However, RSV possesses several evasion mechanisms, and both the NS1 protein and the G protein can suppress the type I IFN response (60). A vaccine that induces a powerful type I IFN secretion within its response could be considered a good candidate against RSV.

$\mathrm{CD}^{+}{ }^{+}$cells play a critical role in RSV-clearance (61). Murine studies of RSV demonstrate a protective role for memory $\mathrm{CD}^{+} \mathrm{T}$ cells in promoting viral clearance and providing protection from reinfection $(61,62)$. Nevertheless, natural RSV infection induces low levels of $\mathrm{CD}^{+} \mathrm{T}$ cells. Thus, it would be advantageous for a vaccine to promote a Th-1 immune response and generate memory $\mathrm{CD}^{+} \mathrm{T}$ cells $(23-25)$. In contrast, $\mathrm{CD} 4^{+} \mathrm{T}$ cells have a controversial role during RSV infection. Following natural infection, $\mathrm{CD} 4^{+} \mathrm{T}$ cells can promote a dysbalanced host response that enhances immunopathology. However, adoptive transfer studies in the mouse model also suggest that $\mathrm{CD} 4^{+} \mathrm{T}$ cells can play a protective role. The induction of a Th-1 polarized immune response that promotes both $\mathrm{CD}^{+}$and $\mathrm{CD}^{+} \mathrm{T}$ cells is essential for a vaccine to induce a protective immune response against RSV.

The decline in neutralizing antibodies after the RSV infection is an important factor in the reinfections that occur in children. Several formulations of vaccines seek to induce neutralizing antibodies in high risk populations and maternal antibodies that will be transferred from the mother to the fetus to protect against early RSV infections. Nevertheless, these formulations have been shown to induce antibodies that are short-lived. Interestingly, intranasal vaccines have demonstrated the ability to induce high levels of neutralizing antibodies and also promote the IgA

\section{REFERENCES}

1. Bont L, Checchia PA, Fauroux B, Figueras-Aloy J, Manzoni P, Paes B, et al. Defining the epidemiology and burden of severe Respiratory Syncytial Virus infection among infants and children in Western Countries. Infect Dis Ther. (2016) 5:271-98. doi: 10.1007/s40121-016-0123-0

2. Modjarrad K, Giersing B, Kaslow DC, Smith PG, Moorthy VS. WHO consultation on Respiratory Syncytial Virus vaccine development report from a World Health Organization Meeting held on 23-24 March 2015. Vaccine. (2016) 34:190-7. doi: 10.1016/j.vaccine.2015.05.093 secretion that is directly associated with a protective immune response against RSV $(43-45,59,63)$.

\section{DISCUSSION}

Severe RSV-induced disease continues to present a major global health burden in high-risk groups such as preterm infants, newborns, elderly populations, and those with many associated comorbidities. There is no licensed vaccine to prevent RSV infections, and the only prophylaxis currently approved by the Food and Drug Administration (FDA) is the monoclonal antibody palivizumab. However, its limited use in high-risk groups (14), as well as the high cost and moderate effectiveness underscore the need for additional options. There remains a critical need to develop safe and effective RSV vaccines and therapeutics to combat RSV disease severity in infants and highrisk populations.

In conclusion a vaccine against RSV that promotes an effective antiviral response must induce a prolonged neutralizing antibody response, Th-1 polarized immunity that promotes both $\mathrm{CD} 8^{+}$ and $\mathrm{CD} 4^{+} \mathrm{T}$ cells, type I IFN secretion and an efficient mucosa immune response.

\section{AUTHOR CONTRIBUTIONS}

JS, LS, and KW wrote and revised the manuscript. GC-M contributed to the revision and editing of the manuscript. $\mathrm{SV}$ and $\mathrm{AK}$ were the lead investigators and revised the manuscript. All authors contributed to the article and approved the submitted version.

\section{FUNDING}

This research was funded by FONDECYT 1190830, 3190590 and the Millennium Institute on Immunology and Immunotherapy P09/016-F. This work was supported by the Department of Microbiology and Immunology at the University of Iowa (to SV) and the National Institute of Allergy and Infectious Diseases of the National Institutes of Health (NIH, R01AI124093 to SV and T32AI007485 to LS).

\section{ACKNOWLEDGMENTS}

AK is a Helen C. Levitt visiting professor at the Department of Microbiology and Immunology of the University of Iowa. RJ, et al. Global burden of acute lower respiratory infections due to Respiratory Syncytial Virus in young children: a systematic review and meta-analysis. Lancet. (2010) 375:1545-55. doi: 10.1016/S0140-6736(10) 60206-1

4. Falsey AR, Hennessey PA, Formica MA, Cox C, Walsh EE. Respiratory Syncytial Virus infection in elderly and high-risk adults. N Engl J Med. (2005) 352:1749-59. doi: 10.1056/NEJMoa043951

5. Krilov LR. Respiratory Syncytial Virus disease: update on treatment and prevention. Exp Rev Anti Infect Ther. (2011) 9:27-32. doi: 10.1586/eri.10.140 
6. Kim HW, Canchola JG, Brandt CD, Pyles G, Chanock RM, Jensen $\mathrm{K}$, et al. Respiratory Syncytial Virus disease in infants despite prior administration of antigenic inactivated vaccine. Am J Epidemiol. (1969) 89:422-34. doi: 10.1093/oxfordjournals.aje.a120955

7. Chin J, Magoffin RL, Shearer LA, Schieble JH, Lennette EH. Field evaluation of a Respiratory Syncytial Virus vaccine and a trivalent parainfluenza virus vaccine in a pediatric population. Am J Epidemiol. (1969) 89:44963. doi: 10.1093/oxfordjournals.aje.a120957

8. Fulginiti VA, Eller JJ, Sieber OF, Joyner JW, Minamitani M, Meiklejohn G. Respiratory virus immunization: a field trial of two inactivated respiratory virus vaccines; an aqueous trivalent paratnfluenza virus vaccine and an alumprecipitated Respiratory Syncytial Virus vaccine. Am J Epidemiol. (1969) 89:435-48. doi: 10.1093/oxfordjournals.aje.a120956

9. Kapikian AZ, Mitchell RH, Chanock RM, Shvedoff RA, Stewart CE. An epidemiologic study of altered clinical reactivity to Respiratory Syncytial (RS) virus infection in children previously vaccinated with an inactivated RS virus vaccine. Am J Epidemiol. (1969) 89:405-21. doi: 10.1093/oxfordjournals.aje.a120954

10. Olson MR, Varga SM. CD8 T cells inhibit Respiratory Syncytial Virus (RSV) vaccine-enhanced disease. J Immunol. (2007) 179:5415-24. doi: 10.4049/jimmunol.179.8.5415

11. Olson MR, Hartwig SM, Varga SM. The number of Respiratory Syncytial Virus (RSV)-specific memory CD8 T cells in the lung is critical for their ability to inhibit RSV vaccine-enhanced pulmonary eosinophilia. J Immunol. (2008) 181:7958-68. doi: 10.4049/jimmunol.181.11.7958

12. Knudson CJ, Hartwig SM, Meyerholz DK, Varga SM. RSV vaccine-enhanced disease is orchestrated by the combined actions of distinct CD4 T cell subsets. PLOS Pathog. (2015) 11:e1004757. doi: 10.1371/journal.ppat.1004757

13. Delgado MF, Coviello S, Monsalvo AC, Melendi GA, Hernandez JZ, Batalle JP, et al. Lack of antibody affinity maturation due to poor Toll-like receptor stimulation leads to enhanced Respiratory Syncytial Virus disease. Nat Med. (2009) 15:34-41. doi: 10.1038/nm.1894

14. Village EG. Palivizumab, a humanized Respiratory Syncytial Virus monoclonal antibody, reduces hospitalization from Respiratory Syncytial Virus infection in high-risk infants. Pediatrics. (1998) 102:531-7. doi: $10.1542 /$ peds.102.3.531

15. Subramanian KNS, Weisman LE, Rhodes T, Ariagno R, Sánchez PJ, Steichen J, et al. Safety, tolerance and pharmacokinetics of a humanized monoclonal antibody to Respiratory Syncytial Virus in premature infants and infants with bronchopulmonary dysplasia. Pediatr Infect Dis J. (1998) 17:1105. doi: 10.1097/00006454-199802000-00006

16. Sáez-Llorens X, Castaño E, Null D, Steichen J, Sánchez PJ, Ramilo O, et al. Safety and pharmacokinetics of an intramuscular humanized monoclonal antibody to Respiratory Syncytial Virus in premature infants and infants with bronchopulmonary dysplasia. Pediatr Infect Dis J. (1998) 17:78791. doi: 10.1097/00006454-199809000-00007

17. Village EG. Updated guidance for palivizumab prophylaxis among infants and young children at increased risk of hospitalization for Respiratory Syncytial Virus infection. Pediatrics. (2014) 134:415-20. doi: 10.1542/peds.2014-1665

18. Kim HW, Arrobio JO, Brandt CD, Wright P, Hodes D, Chanock RM, et al. Safety and antigenicity of temperature sensitive (TS) mutant Respiratory Syncytial Virus (RSV) in infants and children. Pediatrics. (1973) 52:56-63.

19. Malkin E, Yogev R, Abughali N, Sliman J, Wang CK, Zuo F, et al. Safety and immunogenicity of a live attenuated RSV vaccine in healthy RSV-seronegative children 5 to 24 months of age. PLoS ONE. (2013) 8:e77104. doi: 10.1371/journal.pone.0077104

20. McFarland EJ, Karron RA, Muresan P, Cunningham CK, Valentine ME, Perlowski C, et al. Live-attenuated Respiratory Syncytial Virus vaccine candidate with deletion of RNA synthesis regulatory protein M22 is highly immunogenic in children. J Infect Dis. (2018) 217:134755. doi: 10.1093/infdis/jiy040

21. Buchholz UJ, Cunningham CK, Muresan P, Gnanashanmugam D, Sato P, Siberry GK, et al. Live Respiratory Syncytial Virus (RSV) vaccine candidate containing stabilized temperature-sensitivity mutations is highly attenuated in RSV-seronegative infants and children. J Infect Dis. (2018) 217:133846. doi: 10.1093/infdis/jiy066

22. Soto JA, Gálvez NMS, Rivera CA, Palavecino CE, Céspedes PF, Rey-Jurado $\mathrm{E}$, et al. Recombinant BCG vaccines reduce pneumovirus-caused airway pathology by inducing protective humoral immunity. Front Immunol. (2018) 9:2875. doi: 10.3389/fimmu.2018.02875

23. Bueno SM, Gonzalez PA, Cautivo KM, Mora JE, Leiva ED, Tobar HE, et al. Protective T cell immunity against Respiratory Syncytial Virus is efficiently induced by recombinant BCG. Proc Natl Acad Sci USA. (2008) 105:208227. doi: $10.1073 /$ pnas.0806244105

24. Cautivo KM, Bueno SM, Cortes CM, Wozniak A, Riedel CA, Kalergis AM. Efficient lung recruitment of Respiratory Syncytial Virus-specific Th1 cells induced by recombinant bacillus calmette-guérin promotes virus clearance and protects from infection. J Immunol. (2010) 185:763345. doi: 10.4049/jimmunol.0903452

25. Céspedes PF, Rey-Jurado E, Espinoza JA, Rivera CA, Canedo-Marroquín G, Bueno SM, et al. A single, low dose of a cGMP recombinant BCG vaccine elicits protective $\mathrm{T}$ cell immunity against the human Respiratory Syncytial Virus infection and prevents lung pathology in mice. Vaccine. (2017) 35:75766. doi: 10.1016/j.vaccine.2016.12.048

26. Gomez M, Mufson MA, Dubovsky F, Knightly C, Zeng W, Losonsky G. PhaseI study Medi-534, of a live, attenuated intranasal vaccine against Respiratory Syncytial Virus and parainfluenza-3 virus in seropositive children. Pediatr Infect Dis J. (2009) 28:655-8. doi: 10.1097/INF.0b013e318199c3b1

27. Yang C-F, Wang CK, Malkin E, Schickli JH, Shambaugh C, Zuo F, et al. Implication of Respiratory Syncytial Virus (RSV) F transgene sequence heterogeneity observed in Phase 1 evaluation of MEDI-534, a live attenuated parainfluenza type 3 vectored RSV vaccine. Vaccine. (2013) 31:28227. doi: 10.1016/j.vaccine.2013.04.006

28. Cicconi P, Jones C, Sarkar E, Silva-Reyes L, Klenerman P, de Lara $\mathrm{C}$, et al. First-in-human randomized study to assess the safety and immunogenicity of an investigational Respiratory Syncytial Virus (RSV) vaccine based on chimpanzee-adenovirus-155 viral vector-expressing RSV fusion, nucleocapsid, and antitermination viral proteins. Clin Infect Dis. (2020) 70:2073-81. doi: 10.1093/cid/ciz653

29. Green CA, Scarselli E, Sande CJ, Thompson AJ, de Lara CM, Taylor KS, et al. Chimpanzee adenovirus- and MVA-vectored Respiratory Syncytial Virus vaccine is safe and immunogenic in adults. Sci Transl Med. (2015) 7:300ra126. doi: 10.1126/scitranslmed.aac5745

30. Green CA, Scarselli E, Voysey M, Capone S, Vitelli A, Nicosia A, et al. Safety and immunogenicity of novel Respiratory Syncytial Virus (RSV) vaccines based on the RSV viral proteins F, N and M2-1 encoded by simian adenovirus (PanAd3-RSV) and MVA (MVA-RSV); protocol for an open-label, dose-escalation, single-centre, phase 1 cl. BMJ Open. (2015) 5:e008748. doi: 10.1136/bmjopen-2015-008748

31. Green CA, Sande CJ, Scarselli E, Capone S, Vitelli A, Nicosia A, et al. Novel genetically-modified chimpanzee adenovirus and MVA-vectored Respiratory Syncytial Virus vaccine safely boosts humoral and cellular immunity in healthy older adults. J Infect. (2019) 78:382-92. doi: 10.1016/j.jinf.2019.02.003

32. Leroux-Roels G, De Boever F, Maes C, Nguyen TL-A, Baker S, Gonzalez Lopez A. Safety and immunogenicity of a Respiratory Syncytial Virus fusion glycoprotein F subunit vaccine in healthy adults: results of a phase 1, randomized, observer-blind, controlled, dosage-escalation study. Vaccine. (2019) 37:2694-703. doi: 10.1016/j.vaccine.2019.04.011

33. August A, Glenn GM, Kpamegan E, Hickman SP, Jani D, Lu H, et al. A Phase 2 randomized, observer-blind, placebo-controlled, dose-ranging trial of aluminum-adjuvanted Respiratory Syncytial Virus F particle vaccine formulations in healthy women of childbearing age. Vaccine. (2017) 35:374959. doi: 10.1016/j.vaccine.2017.05.045

34. Schwarz TF, McPhee RA, Launay O, Leroux-Roels G, Talli J, Picciolato M, et al Immunogenicity and safety of 3 formulations of a Respiratory Syncytial Virus candidate vaccine in nonpregnant women: a phase 2, randomized trial. J Infect Dis. (2019) 220:1816-25. doi: 10.1093/infdis/jiz395

35. Falloon J, Yu J, Esser MT, Villafana T, Yu L, Dubovsky F, et al. An adjuvanted, postfusion $\mathrm{F}$ protein-based vaccine did not prevent Respiratory Syncytial Virus illness in older adults. J Infect Dis. (2017) 216:136270. doi: 10.1093/infdis/jix503

36. Boyoglu-Barnum S, Chirkova T, Anderson LJ. Biology of infection and disease pathogenesis to guide RSV vaccine development. Front Immunol. (2019) 10:1675. doi: 10.3389/fimmu.2019.01675

37. Cheon IS, Kim JY, Choi Y, Shim B-S, Choi J, Jung D-I, et al. Sublingual immunization with an RSV G glycoprotein fragment primes IL-17-mediated 
immunopathology upon Respiratory Syncytial Virus infection. Front Immunol. (2019) 10:567. doi: 10.3389/fimmu.2019.00567

38. Ye X, Iwuchukwu OP, Avadhanula V, Aideyan LO, McBride TJ, FerlicStark LL, et al. Antigenic site-specific competitive antibody responses to the fusion protein of Respiratory Syncytial Virus were associated with viral clearance in hematopoietic cell transplantation adults. Front Immunol. (2019) 10:706. doi: 10.3389/fimmu.2019.00706

39. Aranda SS, Polack FP. Prevention of pediatric Respiratory Syncytial Virus lower respiratory tract illness: perspectives for the next decade. Front Immunol. (2019) 10:1006. doi: 10.3389/fimmu.2019.01006

40. Schepens B, Sedeyn K, Vande Ginste L, De Baets S, Schotsaert M, Roose $\mathrm{K}$, et al. Protection and mechanism of action of a novel human Respiratory Syncytial Virus vaccine candidate based on the extracellular domain of small hydrophobic protein. EMBO Mol Med. (2014) 6:143654. doi: 10.15252/emmm.201404005

41. Langley JM, MacDonald LD, Weir GM, MacKinnon-Cameron D, Ye L, McNeil S, et al. A Respiratory Syncytial Virus vaccine based on the small hydrophobic protein ectodomain presented with a novel lipid-based formulation is highly immunogenic and safe in adults: a first-in-humans study. J Infect Dis. (2018) 218:378-87. doi: 10.1093/infdis/jiy177

42. Karron RA, Luongo C, Thumar B, Loehr KM, Englund JA, Collins $\mathrm{PL}$, et al. A gene deletion that up-regulates viral gene expression yields an attenuated RSV vaccine with improved antibody responses in children. Sci Transl Med. (2015) 7:312ra175. doi: 10.1126/scitranslmed. aac8463

43. Ascough S, Vlachantoni I, Kalyan M, Haijema B-J, Wallin-Weber S, DijkstraTiekstra M, et al. Local and systemic immunity against Respiratory Syncytial Virus induced by a novel intranasal vaccine. A randomized, double-blind, placebo-controlled clinical trial. Am J Respir Crit Care Med. (2019) 200:48192. doi: 10.1164/rccm.201810-19210C

44. Lee J-Y, Chang J. Universal vaccine against Respiratory Syncytial Virus A and B subtypes. PLoS ONE. (2017) 12:e0175384. doi: 10.1371/journal.pone.0175384

45. Yang K, Varga SM. Mucosal vaccines against Respiratory Syncytial Virus. Curr Opin Virol. (2014) 6:78-84. doi: 10.1016/j.coviro.2014.03.009

46. Morabito KM, Ruckwardt TR, Redwood AJ, Moin SM, Price DA, Graham BS. Intranasal administration of RSV antigen-expressing MCMV elicits robust tissue-resident effector and effector memory CD8+ $\mathrm{T}$ cells in the lung. Mucosal Immunol. (2017) 10:545-54. doi: 10.1038/mi.2016.48

47. Li H, Callahan C, Citron M, Wen Z, Touch S, Monslow MA, et al. Respiratory Syncytial Virus elicits enriched CD8+ T lymphocyte responses in lung compared with blood in African green monkeys. PLoS ONE. (2017) 12:e0187642. doi: 10.1371/journal.pone.0187642

48. Tregoning JS, Yamaguchi Y, Harker J, Wang B, Openshaw PJM. The role of $\mathrm{T}$ cells in the enhancement of Respiratory Syncytial Virus infection severity during adult reinfection of neonatally sensitized mice. J Virol. (2008) 82:411524. doi: 10.1128/JVI.02313-07

49. Culley FJ, Pollott J, Openshaw PJM. Age at first viral infection determines the pattern of T cell-mediated disease during reinfection in adulthood. J Exp Med. (2002) 196:1381-6. doi: 10.1084/jem.20020943

50. You D, Marr N, Saravia J, Shrestha B, Lee GI, Turvey SE, et al. IL-4R $\alpha$ on CD4 $+\mathrm{T}$ cells plays a pathogenic role in Respiratory Syncytial Virus reinfection in mice infected initially as neonates. J Leukoc Biol. (2013) 93:93342. doi: 10.1189/jlb.1012498

51. Shrestha B, You D, Saravia J, Siefker DT, Jaligama S, Lee GI, et al. IL-4R $\alpha$ on dendritic cells in neonates and Th2 immunopathology in
Respiratory Syncytial Virus infection. J Leukoc Biol. (2017) 102:15361. doi: 10.1189/jlb.4A1216-536R

52. Lukacs NW, Smit JJ, Mukherjee S, Morris SB, Nunez G, Lindell DM. Respiratory virus-induced TLR7 activation controls IL-17-associated increased mucus via IL-23 regulation. J Immunol. (2010) 185:22319. doi: 10.4049/jimmunol.1000733

53. Mukherjee S, Lindell DM, Berlin AA, Morris SB, Shanley TP, Hershenson $\mathrm{MB}$, et al. IL-17-induced pulmonary pathogenesis during respiratory viral infection and exacerbation of Allergic Disease. Am J Pathol. (2011) 179:24858. doi: 10.1016/j.ajpath.2011.03.003

54. Mangodt TC, Van Herck MA, Nullens S, Ramet J, De Dooy JJ, Jorens PG, et al. The role of Th17 and Treg responses in the pathogenesis of RSV infection. Pediatr Res. (2015) 78:483-91. doi: 10.1038/pr.2015.143

55. Openshaw PJ, Chiu C. Protective and dysregulated T cell immunity in RSV infection. Curr Opin Virol. (2013) 3:468-74. doi: 10.1016/j.coviro.2013.05.005

56. Christiaansen AF, Syed MA, Ten Eyck PP, Hartwig SM, Durairaj L, Kamath SS, et al. Altered Treg and cytokine responses in RSV-infected infants. Pediatr Res. (2016) 80:702-9. doi: 10.1038/pr.2016.130

57. Durant LR, Makris S, Voorburg CM, Loebbermann J, Johansson C, Openshaw PJM. Regulatory $\mathrm{T}$ cells prevent Th2 immune responses and pulmonary eosinophilia during Respiratory Syncytial Virus infection in mice. J Virol. (2013) 87:10946-54. doi: 10.1128/JVI.01295-13

58. Fulton RB, Meyerholz DK, Varga SM. Foxp3 + CD4 regulatory $\mathrm{T}$ cells limit pulmonary immunopathology by modulating the CD8 $\mathrm{T}$ cell response during Respiratory Syncytial Virus infection. J Immunol. (2010) 185:238292. doi: 10.4049/jimmunol.1000423

59. Hijano DR, Siefker DT, Shrestha B, Jaligama S, Vu LD, Tillman H, et al. Type I interferon potentiates IgA immunity to Respiratory Syncytial Virus infection during infancy. Sci Rep. (2018) 8:11034. doi: 10.1038/s41598-018-29456-w

60. Tognarelli EI, Bueno SM, González PA. Immune-modulation by the human Respiratory Syncytial Virus: focus on dendritic cells. Front Immunol. (2019) 10:810. doi: 10.3389/fimmu.2019.00810

61. Graham BS, Bunton LA, Wright PF, Karzon DT. Role of T lymphocyte subsets in the pathogenesis of primary infection and rechallenge with Respiratory Syncytial Virus in mice. J Clin Invest. (1991) 88:102633. doi: 10.1172/JCI115362

62. Schmidt ME, Knudson CJ, Hartwig SM, Pewe LL, Meyerholz DK, Langlois RA, et al. Memory CD8 T cells mediate severe immunopathology following Respiratory Syncytial Virus infection. PLOS Pathog. (2018) 14:e1006810. doi: 10.1371/journal.ppat.1006810

63. Salisch NC, Izquierdo Gil A, Czapska-Casey DN, Vorthoren L, Serroyen J, Tolboom J, et al. Adenovectors encoding RSV-F protein induce durable and mucosal immunity in macaques after two intramuscular administrations. NPJ Vaccines. (2019) 4:54. doi: 10.1038/s41541-019-0150-4

Conflict of Interest: The authors declare that the research was conducted in the absence of any commercial or financial relationships that could be construed as a potential conflict of interest.

Copyright (c) 2020 Soto, Stephens, Waldstein, Canedo-Marroquín, Varga and Kalergis. This is an open-access article distributed under the terms of the Creative Commons Attribution License (CC BY). The use, distribution or reproduction in other forums is permitted, provided the original author(s) and the copyright owner(s) are credited and that the original publication in this journal is cited, in accordance with accepted academic practice. No use, distribution or reproduction is permitted which does not comply with these terms. 